\title{
PROFESSIONAL AND AMATEUR LOBBYISTS \\ IN THE ARKANSAS GENERAL ASSEMBLY
}

\author{
Donald E. Whistler \\ (University of Central Arkansas) \\ Charles DeWitt Dunn \\ (Henderson State University)
}

\section{Introduction and Literature}

In a democracy, the public interest requires open access and communication between citizens and legislators. Indeed, given that politics consists of authoritatively allocating values, no subset of which can make a universally accepted claim to be the truth, the political process which provides the widest practicable access and communication of different interests is most appropriate (Dahl, 1970; Lindsay, 1962; Pennock, 1979; Plamenatz, 1973; Thorson, 1962: 128-149).

The interactions of American state legislators and lobbyists, however, can be mutually beneficial. Their self-interests might be served by a restricted network of access and communication. In fact, symbiotic legislator-lobbyist interactions are made probable by two inherent conditions. First, legislators and lobbyists are elites who reflect a state's socio-economic structures; consequently, they share values, experiences and self-interests that enhance symbiotic communications (Zeigler and Baer, 1969: 39-40). The temptation to restrict access to those who share values and policy preferences is a natural exercise of self-interest.

Second, a legislature is the arena in which legislators make decisions vital to the interests represented by lobbyists. To do so, they need information provided by lobbyists regarding the impact of possible decisions on the interests. Moreover, legislators may require the electoral support of interests, while lobbyists are benefitted by legislators who are sympathetic to their interests. That this frequently results in organized interests involvement in American legislators' electoral campaigns is well-known. Presumably, subsequent legislative access is more favorable to electoral supporters.

Access and communication between citizens and legislators are alleged to be more restricted in amateur than professional state legislatures (Citizen's Conference on State Legislatures, 1973). Amateur state legislatures are characterized by biennial sessions, part-time legislators whose private vocation dominates their time and energies and low levels of support staff. Such legislatures are alleged to restrict access because it is thought that a sustained organization is needed for effective citizen communication with legislators (Zeigler in Gray, Jacob and Vines, 98); however, amateur legislatures are found in states lacking the economic development to provide a variety of interests with the resources to 
sustain organization (Morehouse, 1981: 491-492). In addition, the more homogeneous socio-economic backgrounds of legislators and lobbyists in amateur state legislatures should enhance the communality of their values and policy preferences.

The Arkansas General Assembly is classified as amateur (Henry, 1980: 111-112). (Legislators prefer the term "citizen legislature." We follow standard nomenclature, although as our results will show, the legislators' term may be more descriptive.) The state's economy is agriculturally-oriented and homogeneous (Morehouse, 1981: 513-514), one political party is overwhelmingly dominant in state and local politics (Rosenthal, 1981: 140) and there are a small variety of interest groups which are rated as strong (English and Carroll, 1983; Whistler and Dunn, 1983). Under the one-party circumstances of the Democrat party in Arkansas, state legislative politics become "no-party" politics. Ephemeral factions revolving around individual political and private groups inside and outside the General Assembly continue to be the modus operandi of Arkansas state legislative politics (Bass and DeVries, 1976: 87-89; Key, 1949: 186). Under such circumstances, access and communications might be expected to be influenced by insider or outsider status within the configuration of factions.

In sum, American state legislators and lobbyists operate in an arena where their interactions can be mutually beneficial. They are elites who share a background of similar social and economic experiences. In less economically diverse states - such as Arkansas - fewer interests exist to organize participation in legislators' electoral campaigns or in communicating interests' preferences to legislators. Access and communication might, then, be negatively affected.

\section{Hypotheses/Expectations}

For purposes of hypothesis-testing, we anticipate that lobbyists who represent a small number of organized groups important to Arkansas' socio-economic situation will form a set of "insiders" with respect to legislative access and communication. "Insider-lobbyists" should exhibit background characteristics that demonstrate more political experience, indicate a higher commitment to lobbying, and are similar to the legislators' backgrounds. They also should show greater understanding of what tactics are most effective in lobbying the General Assembly and, being integral to the legislative process, they should feel positive about their contributions to democracy. Finally, the "insider-lobbyists" should be more effective at getting desired results. We evaluate these expectations by:

1. the configuration of Arkansas interest groups perceived as strong(Table 1);

2. what type of lobbyists (see section below on lobbyist types) represents which groups; 
3. lobbyists' background characteristics of gender, age, and education (Tables 2-4);

4. lobbyists' political experience (Tables 5-8):

5. lobbyists' commitment to lobbying and the value of lobbying to democracy (Tables 9-10);

6. lobbyists' understanding of effective lobbying techniques (Table 11);

7. lobbyists' involvement in their organizations strategy-making (Tables 12-13);

8. lobbyists' perception of their effectiveness at getting what they want from the legislature (Table 14).

The brief methodology section below describes our typology of lobbyists. The "professional" designation is our measure of "insider-lobbyists" and "amateur" is intended to index "outsiders" to the General Assembly's legislative process.

\section{Typology of Lobbyists}

For the purpose of this study, lobbyists who are full-time employees of the organization will be called professionals. Conversely, amateurs are defined as unsalaried part-timers. We expect amateurs to be less politically experienced than professionals, to be less committed to lobbying, both occupationally and in a systemic sense, and to be less like their legislative counter-parts than professionals. An intermediate group which fits neatly into neither category is termed marginals. Marginals may be paid for their lobbying efforts, but work only on a part-time or occasional basis. Or, in some cases, they are unpaid, but devote fulltime to their lobbying efforts.

Professionals: Paid; Full-Time employees of the organization they lobby for

Marginals: Paid; Part-Time or Occasional/Unpaid; Full-Time Amateurs: Unpaid; Part-Time or Occasional

\section{Data}

The data is from two surveys. The basic survey is a sample of thirty-six lobbyists randomly selected from a list of 318 registered with the Secretary of the Arkansas Senate. The sample, while small, is random and is greater than ten percent of the total population. Face-to-face interviews were conducted with each lobbyist during the 1983 regular session of the General Assembly. The second survey of eighty-four (of 100) representatives and thirty (of 35) state senators is published elsewhere (Whistler and Dunn, 1983) and is included here 
only as needed to embellish the lobbyist data.

\section{Findings}

In Arkansas a limited number of interest groups are consistently identified as important in the General Assembly (English and Carroll, 1983: 45). In our samples, there is considerable agreement among lobbyists and legislators (Table 1) that the Arkansas Education Association (AEA), financial institutions, utilities, the state Highway Commission, and the Farm Bureau are the most "influential" organizations working in the General Assembly. While these groups correspond to the predominant economic structure of the state, the list is incomplete. The most likely explanation for this incompleteness is that important groups are active in the legislature only when their interests are challenged. Longitudinal data is needed to confirm this.

\section{Table 1: Lobbyists and Legislators' Perceptions of Interest Group Strength}

(Percent)

"There is a lot of talk about the influence that special interest groups have on the legislative process. Which interest groups in Arkansas tend to exert the most influence on legislative voting behavior?"

\section{Group}

AEA

Financial Institutions

Farm Bureau

Highway Commission

Utilities

Labor

Trucking

Liquor

American Association

of Retired Persons

ACORN

ACLU

\section{Lobbyists (1983) Legislators (1981)}

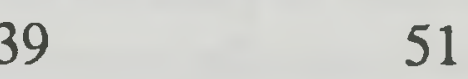

$19 \quad 10$

$28 \quad 7$

$25 \quad 6$

425

34

25 *

11 *

$\begin{array}{ll}8 & * \\ 6 & * \\ 3 & *\end{array}$

Asterisks indicate mentions of less than 1 percent. We omitted those percentages that were less than 1 percent. Among legislators there were several other mentions of less than 1 percent resulting in the legislator column adding to less than 100 percent.

Note: Lobbyists and legislators were permitted to list several "influential"interest groups; therefore, percentages do not add to $100 \%$. 
The occasional anomalous citing of the Arkansas Community Organization for Reform Now (ACORN) and the American Civil Liberties Union (ACLU) by lobbyists-neither of which is viewed positively nor as being particularly effective by legislators-suggests a pattern that will emerge more clearly as we progress through the study: that all types of lobbyists are rather sanguine concerning their influence.

The associations represented by lobbyists reveal considerable support for the expectation that groups important to an on-going economic system are most organized. Organizations employing "professionals" typically are banks, utilities, local government and associations representing a particular industry. "Marginals" are likely to be officers of the organization they represent and are more likely to be representatives of non-profit groups. "Amateurs" are most inclined to represent issue-oriented, volunteer groups. (Specific group names are not listed to protect the confidentiality of the interviewees.)

\section{Characteristics of Lobbyists}

To examine shared affinities, we compared the lobbyists with legislators on three dimensions: gender, age, and educational background.

Table 2: Gender Distribution of Lobbyists and Legislators

\begin{tabular}{|c|c|c|c|}
\hline & Male & Femal & \\
\hline Legislators & 94.8 & 5.2 & $\mathrm{n}=135$ \\
\hline Professionals & 100.0 & 0.0 & $\mathrm{n}=11$ \\
\hline Marginals & 63.6 & 36.4 & $\mathrm{n}=11$ \\
\hline Amateurs & 57.1 & 42.9 & $\mathrm{n}=14$ \\
\hline
\end{tabular}

Table 3: Age Distribution of Lobbyists and Legislators (Percent)

\begin{tabular}{lccccc}
\multicolumn{7}{c}{ Age Groupings } \\
\\
Legislators & 35 \& under & $36-45$ & $46-55$ & 56 \& over & \\
Professionals & 11.9 & 23.9 & 35.8 & 28.4 & $\mathrm{n}=135$ \\
Marginals & 9.1 & 45.5 & 27.3 & 18.2 & $\mathrm{n}=11$ \\
Amateurs & 36.4 & 27.3 & 27.3 & 9.1 & $\mathrm{n}=11$ \\
& 21.4 & 21.4 & 21.4 & 35.7 & $\mathrm{n}=14$
\end{tabular}


Table 4: Education Distribution of Lobbyists and Legislators (Percent)

\begin{tabular}{lcccccc}
\multicolumn{7}{c}{ Educational Level } \\
& High School & Some & College & Advanced \\
or less & College & Degree & Degree & \\
Legislators & 11.6 & 23.3 & 33.0 & 32.1 & $\mathrm{n}=112$ \\
Professionals & 18.2 & 9.1 & 36.4 & 36.4 & $\mathrm{n}=11$ \\
Marginals & 9.1 & 9.1 & 36.4 & 45.5 & $\mathrm{n}=11$ \\
Amateurs & 7.1 & 14.3 & 28.6 & 50.0 & $\mathrm{n}=14$
\end{tabular}

Tables $2-4$ confirm the affinities between professional lobbyists and legislators. Professionals clearly share more of the same background characteristics with legislators than do marginals and amateurs. Professional lobbyists, like legislators, are characterized by being well-educated, middle-aged males. Amateurs are considerably more likely to possess advanced degrees, be over 55 years of age, and be female than are the legislators or either of the other two categories of lobbyists.

\section{Political Activity}

Professionals are considerably more apt to be Democrats than are marginals or amateurs. Table 5 indicates that amateurs are more prone to identify themselves as Independents.

\section{Table 5: Lobbyists and Political Party Identification} (Percent)

$\begin{array}{lcccc} & & \text { Democrat } & \text { Republican } & \text { Independent } \\ \text { Professionals } & \mathrm{n}=10 & 80.0 & 0.0 & 20.0 \\ \text { Marginals } & \mathrm{n}=11 & 63.6 & 0.0 & 36.4 \\ \text { Amateurs } & \mathrm{n}=14 & 42.9 & 7.1 & 50.0\end{array}$

Given the political party composition of the Arkansas General Assembly, a heavy Democrat preference among professionals would indicate an insider position in electoral politics. This expectation is confirmed at least tentatively by the data (Table 5 ).

Furthermore, professionals appear to be involved in more political activi- 
ties than marginals or amateurs. Table 6 reveals a comparison of means among the groups based on the average number of political activities engaged in by the lobbyist.

Table 6: Average Political Activity of Lobbyists

Professionals

Marginals

Amateurs
Mean Activities*

3.82

3.00

3.50

* Scores ranged from 0-7. The activities are listed in Table 7.

Some variation exists in the specific types of political activity engaged in by the different classifications of lobbyists. Perhaps the most significant revelation of Table 7 is the rather high level of activity by all categories of lobbyists. This is not surprising given the elite status of lobbyists and, of course, their interest in the outcome of state politics. Nonetheless, some differences do exist.

\section{Table 7: Lobbyists and Political Activities}

(Percent)

Activity

Attended Rallies

Actively Campaigned

Contributed Money

Raised Campaign Funds

Held Party Office

Candidate for Public Office

Held Public Office
Lobbyists (\% indicating activity)

$\begin{array}{ccc}\text { Professionals } & \text { Marginals } & \text { Amateurs } \\ 90.9 & 81.8 & 92.9 \\ 72.7 & 81.8 & 71.4 \\ 90.9 & 72.7 & 85.7 \\ 72.7 & 45.5 & 50.0 \\ 18.2 & 0.0 & 14.3 \\ 18.2 & 9.1 & 28.6 \\ 18.2 & 9.1 & 7.1 \\ \mathrm{n}=11 & \mathrm{n}=11 & \mathrm{n}=14\end{array}$

Professionals are somewhat more likely to have contributed money to a political campaign than marginals and amateurs (although an overwhelming percentage of each group has done so). Also, professionals are considerably more inclined to have "raised campaign funds" than marginals and amateurs. This fits the mode of campaign financing in Arkansas General Assembly elections (Hilliard, 1983: 56-65) and suggests an insider position with regard to electoral politics. Amateurs are more likely to have sought public office than any other category, but professionals have a propensity to actually have held both public 
and party offices, suggesting an inside position in General Assembly electoral politics for professionals.

Given the very high Democratic party identification of the professionals, it seems reasonable to assume that their previous political activities were on behalf of Democrat candidates, particularly at the state level. In light of their Democratic party affiliation and pattern of campaign contributions, we suspect, that the previous political activities of professionals are more on behalf of legislatorinsiders in the General Assembly. Perhaps marginals and amateurs may be more supportive of the electoral efforts of others who-like themselves-are "outsiders".

Table 8: Years Experience Lobbying (Percent)

"Prior to this legislative sessions, how much experience have you had as a lobbyist—specifically, how many years?"

$\begin{array}{lccccc} & 0-1 \text { years } & 2-5 \text { years } & 6-10 \text { years } & 11 \text { \& over years } \\ \text { Professionals } & 9.1 & 9.1 & 27.3 & 54.5 & \mathrm{n}=11 \\ \text { Marginals } & 18.2 & 36.4 & 27.3 & 18.2 & \mathrm{n}=11 \\ \text { Amateurs } & 42.9 & 21.4 & 21.4 & 14.3 & \mathrm{n}=14\end{array}$

Finally, professionals are much more experienced in the legislative process than either marginals or amateurs (Table 8). Over half of the professionals have eleven or more years experience compared to less than one-fourth and one-eighth of the other groups, respectively. Whether "years of experience" produces superior results in the lobbying process remains undetermined. Obviously, conventional wisdom would support such a hypothesis.

\section{Commitment to Lobbying}

Professionals are expected to maintain a much higher commitment to lobbying as a long-term personal (or occupational) goal. Table 9 displays that professionals are considerably more likely to expect to continue lobbying activities. Over 80 percent would continue lobbying even if employment with their present organization were to be ended.

Table 9: Lobbyists' Commitment to Lobbying (Percent Indicating They Would Continue Lobbying)

"Do You think you would continue to be a lobbyist if you did not represent 


\begin{tabular}{lcccc}
\multicolumn{1}{c}{ Yes } & No & Don't Know & \\
Professionals & 81.8 & 18.2 & 0.0 & $\mathrm{n}=11$ \\
Marginals & 54.5 & 18.2 & 27.3 & $\mathrm{n}=11$ \\
Amateurs & 42.9 & 57.1 & 0.0 & $\mathrm{n}=14$
\end{tabular}

Less than one-half the amateurs, on the other hand, (Table 9) indicated that they would continue lobbying if they no longer worked for their present organization. Slightly more than one-half of the marginals would continue their lobbying for other groups.

Table 10: Lobbying and Support for Democracy (Mean Value)

"How healthy do you feel lobbying is for our Democracy?"

Response from " 0 " (not healthy) to " 8 " (very healthy).

Professionals

Marginals

Amateurs

\section{Mean Value}

7.55

6.55

5.86

Professionals tend to view lobbying as being "healthy to democracy," while marginals and amateurs give the activity significantly lower value (Table 10). Of course, it may be self-serving for professionals to congratulate themselves on their contributions to the "health of democracy". But beyond the human tendency toward self-aggrandizement, we suspect that the positive evaluation of lobbying results from the professionals' sense of involvement and satisfaction with the on-going process. Amateurs, on the other hand, may reject (or are more negative toward) a process in which they participate occasionally and in which they may be less successful in achieving their specific policy preferences.

\section{Communication Techniques}

Overall, lobbyists and legislators have very similar ratings of which communication techniques are most effective (Table 11). Spearman Rho rank-order coefficients between the ranking of each type of lobbyist and the legislators are all over 0.9. (These are not in a table.) However, there are differences that suggest insider-outsider positions. Professional lobbyists placed more emphasis upon the person-to-person communication (either a constituent, themselves or a 
friend), while amateurs relied a bit more upon the formal channels of communication (testifying at hearings and presenting research evidence). These differences are what an insider or outsider position would suggest.

Another of our conceptualized communications dimensions is how lobbying decisions/strategies are determined. Professional lobbyists differ somewhat from the other categories of lobbyists (Table 12). Lobbying strategy is largely determined in all cases through consultation, however, professionals are slightly more likely to implement strategies determined by others. Insofar as reporting requirements are concerned, professionals are somewhat more likely to report to a chief executive officer while amateurs are more inclined to report to a board or committee or, in some cases, to no one at all (see Table 13). This suggests that professional lobbyists represent larger, more permanent types of organizations. Amateurs appear to be more organizational entrepreneurs-those who have organized their own group and largely determine its goals and strategies.

Table 11: Effective Lobbying Techniques: Comparisons of Professionals, Marginals and Amateurs

\author{
Lobbyists Type \\ mean (rank)
}

Technique Professionals Marginals Amateurs Legislators(1981)

$\begin{array}{lllll}\begin{array}{l}\text { Contact by Constituent } \\ \begin{array}{l}\text { Personal Presentation } \\ \text { of Argument }\end{array}\end{array} & 7.6(1) & 7.5(1) & 7.1(1) & 7.3(1) \\ \begin{array}{l}\text { Contact by Non-Legilative } \\ \quad 6.3(3)\end{array} & 6.8(2) & 6.1(4) & 5.0(5) \\ \quad \text { Friend } & 6.4(2) & 6.5(3) & 5.9(6) & 6.1(2) \\ \text { Testifying at Hearing } & 6.1(4) & 6.3(5) & 6.3(2) & 5.4(4) \\ \text { Present Research Results } & 5.5(5) & 6.4(4) & 6.2(3) & 5.5(3) \\ \text { Campaign Contributions } & 5.5(6) & 5.4(6) & 6.0(5) & 3.6(9) \\ \text { Letter Writing Campaign } & 4.0(8) & 4.8(7) & 5.3(7.5) & 3.8(7) \\ \text { Contact by Other Lobbyists } & 3.9(10) & 4.3(8) & 5.3(7.5) & 3.7(8) \\ \text { P. R. Campaign } & 4.7(7) & 4.1(9) & 4.6(10) & 4.0(6) \\ \text { Entertain Legislators } & 3.9(9) & 3.7(10) & 4.0(11) & 2.6(11) \\ \text { Withhold Campaign } & & & & \\ \quad \text { Contributions } & 3.1(12) & 3.1(11) & 3.9(12) & 1.3(13) \\ \text { Publication of Voting } & & & & \\ \quad \text { Record } & 2.2(13) & 2.6(13) & 5.0(9) & 3.0(10) \\ \text { Giving a Party } & 3.2(11) & 3.0(12) & 3.5(13) & 2.2(12) \\ & \mathrm{n}=11 & \mathrm{n}=11 & \mathrm{n}=1 & \mathrm{n}=4\end{array}$

Note: Lobbyists and Legislators were asked to rate each "technique from "0" (ineffective) to " 8 " (effective). "Bribery" was omitted from the lobbyists' survey. It ranked last (mean=.7) among the legislators. 
Table 12: Lobbying and the Determination of Legislative Strategy

(Percent)

"Are lobbying strategies adopted by your organization or group generally provided to you by others, arrived at throughconsultation between you and others, or pretty well determined solely by you?"

Strategy Determined By:

$\begin{array}{lcccc} & \text { Others } & \text { Consultation } & \text { Self } & \\ \text { Professionals } & 18.2 & 63.6 & 18.2 & \mathrm{n}=11 \\ \text { Marginals } & 9.1 & 63.6 & 27.3 & \mathrm{n}=11 \\ \text { Amateurs } & 0.0 & 78.6 & 21.2 & \mathrm{n}=14\end{array}$

Table 13: Lobbyists as Part of the Organization Reporting Requirements (Percent)

"When you are engaged in lobbying, to whom, if anyone, do you report (title)?"

$\begin{array}{lccllcll} & \text { Chief } & \text { Regional } & \text { Board } & & & \\ & \text { Executive } & \text { Natl. Office } & \text { or Com. } & \text { Other } & \text { Nobody } & \\ \text { Professionals } & 54.5 & 0.0 & 36.4 & 9.1 & 0.0 & \mathrm{n}=11 \\ \text { Marginals } & 36.4 & 36.4 & 27.3 & 0.0 & 0.0 & \mathrm{n}=11 \\ \text { Amateurs } & 21.2 & 7.1 & 35.7 & 0.0 & 35.7 & \mathrm{n}=14\end{array}$

Table 14: Perceived Effectiveness of Lobbyist Types

"As a lobbyists, how much impact do you feel you have in shaping legislation of interest to you or your organization?"

$\begin{array}{ll}\text { Professional } & 6.2 \\ \text { Marginal } & 6.3 \\ \text { Amateur } & 5.7\end{array}$

These are means. The range is $0-8$. 


\section{Insiders and Outsiders, So What?}

The end result of our reasoning process is that "insiders" (professional lobbyists) should be the most effective at getting what they want. However, our data do not strongly support this. Table 14 shows the professionals are only somewhat more likely to rate their own effectiveness more highly than amateurs. While the difference in effectiveness is in the predicted direction, it is small.

\section{Summary}

We anticipated that the Arkansas agricultural economy would produce a limited number of interest groups from which professional lobbyists would have an "insider" advantage. Dividing lobbyists into professional (paid, full-timers), marginals (paid, but part-timers), and amateur (unpaid, part-timers), we find that professional lobbyists:

1. are more likely to represent an organization named as active in Arkansas politics and possessed of organizational resources known to be important for lobbying influence in a legislature;

2. share a closer affinity with legislators on education, age and gender; 3. are much more experienced, committed to lobbying as a vocation, and positive about the value of lobbying for a democracy;

4. are likely to be interwoven with the General Assembly's electoral politics outside the legislative process;

5. are more aware of what methods of communication are most effective in the legislative process;

6. determine legislative strategies in consultation with a board or committee or chief executive, while amateurs are organizational-entrepreneurs who "report" to themselves or represent a regional/national organization.

Our expectation that professional or "insider" lobbyists would be more effective than amateur or "outsider" lobbyists is not strongly supported. Professional lobbyists perceive themselves as only somewhat more effective than amateurs do (professional $=6.2$, amateur $=5.7$ on 8 -point scale). Of course, this may be self-deception or self-serving careerism - to admit low effectiveness would reduce the need for one's services. However, the Arkansas General Assembly's norms and operations corroborate the lobbyists' self-perceptions.

\section{Conclusions}

Lobbyists of different ilks may perceive themselves as effective because the Arkansas General Assembly enacts most measures that are introduced, 
having the highest bill-passage rate of any American state legislature (Rosenthal, 258). It operates upon the premise of enacting constituency-initiated matters that are not strongly opposed. This operating premise is consistent with a "citizen legislature" orientation, and provides for potentially widespread access and communication between citizens and state legislators.

\section{References}

Bass, Jack and Walter De Vries (1976). The Transformation of Southern Politics. New York: Basic Books.

Citizens Conference on State Governments (1973). The Sometimes Governments. Kansas City, Mo.: Citizen Conference on State Legislatures.

Dahl, Robert A. (1970). A Preface to Democratic Theory. Chicago: University of Chicago Press.

Dunn, Charles DeWitt and Donald E. Whistler (1986). "Lobbying in a State Legislature: Another Look at Communications Techniques." Southeastern Political Review. Vol. XIV., No. 2., pp. 101-108.

Eckstein, Harry in Frank Lindenfeld, ed. (1968). Reader in Political Sociology. New York: Funk and Wagnall's.

English, Arthur and John J. Carroll (1983). Citizens Manual to the Arkansas General Assembly. Institute of Politics and Government, Little Rock, Arkansas.

, (1985). "Outsiders and the Amateur Legislature: A Case Study of Legislative Politics." Arkansas Political Science Journal: 22-34.

Eulau, Heinz and John C. Wahlke, eds. (1978). The Politics of Representation. Beverly Hills, California: Sage Publications.

Fiorina, Morris (1977a). Congress: Keystone of the Washington Establishment. New Haven: Yale University Press.

(1977b). "The Case of the Vanishing Marginals: The Bureaucracy Did It," American Political Science Review, Vol. LXXI, pp. 177-81.

Gray, Virginia, Herbert Jacob, and Kenneth N. Vines, eds. (1983). Politics in the American States. Boston: Little, Brown and Company.

Hayes, Michael (1981). Lobbyists and Legislators. New Brunswick, New Jersey: Rutgers University Press.

Henry, Nicholas (1980). Governing at the Grassroots. Englewood Cliffs, New Jersey: Prentice-Hall.

Hilliard, Deb (1983). "Financial Support for Women in Arkansas State Legislative Campaigns." Arkansas Political Science Journal, Vol. 4, No. 1, pp. 56-65.

Key, V.O., Jr. (1967). Public Opinion and the American Democracy. New York: Knopf. (1949). Southern Politics. New York: A. A. Knopf.

Ladd, Everett Carl (1983). Where Have All the Voters Gone? New York: Norton.

Lindsay, A.D. (1962). The Modern Democratic State. New York: Oxford.

Longley, Lawrence D. (1967). "Interest Group Interaction in a Legislative System." Journal of Politics 29, pp. 637-658.

Malbin, Michael (1977). Unelected Representatives. New York: Basic Books, Inc., Publishers.

Milbrath, Lester (1963). The Washington Lobbyists. Chicago: Rand McNally.

Morehouse, Sarah McCally (1981). State Politics, Parties and Policy. New York: Holt, 
Rinehart and Winston.

Oleszek, Walter J. (1984). Congressional Procedures and the Policy Process. Washington, D.C.: C.Q. Press.

Patterson, Samuel, Ronald D. Hedlund and G. Robert Boynton (1975). Representative and Represented: Bases of Public Support for the American Legislature. New York: John Wiley \& Sons.

Pennock, J. Roland (1979). Democratic Political Theory. New Jersey: Princeton University Press.

Plamenatz, John (1973). Democracy and Illusion. London: Longman.

Reid, T.R. (1980). Congressional Odyssey. San Francisco: W.H. Freeman Company.

Richardson, Senator H.L. (1978). What Makes You Think We Read the Bills? Ottawa, Illinois: Caroline House Brooks/Green Hill Publishers.

Rosenthal, Alan (1981). Legislative Life. New York: Harper \& Row.

Smith, Steven S. and Christopher J. Deering (1984). Committees in Congress. Washington, D.C.: C.Q. Press.

Thorson, Thomas Landon (1962). The Logic of Democracy. New York: Holt, Rinehart and Winston.

Whistler, Donald E. and Charles DeWitt Dunn (1983). "Institutional Representation as Institutional Accountability in the Arkansas General Assembly." Arkansas Political Science Journal, Vol. 4, No. 1, pp. 40-55.

Wilson, Graham K. (1981). Interest Groups in the United States. Oxford: Clarendon Press.

Zeigler, Harmon and Michael Baer (1969). Lobbying: Interaction and Influence in American State Legislatures. Belmont, California: Wadsworth Publishing Company. 